\title{
PENERAPAN SASTRA ANAK DALAM PENINGKATAN LITERASI SISWA SD KELAS 1
}

\author{
Penulis \\ Institusi \\ : Kartika ${ }^{1}$, Mas Roro Diah Wahyu Lestari² \\ Email Korespondensi \\ : Fakultas Ilmu Pendidikan, Universitas Muhammadiyah Jakarta \\ DOI \\ : kartikkatika54@gmail.com \\ : $10.53947 /$ perspekt.v1i3.79
}

Kata Kunci:

Sastra Anak

Peningkatan Literasi

Model Pembelajaran

Keywords:

Children's Literature

Literacy Improvement Learning Model

\begin{abstract}
Abstrak
Penelitian ini dilatarbelakangi oleh rendahnya minat baca masyarakat Indonesia terutama pada tingkat sekolah dasar. Penelitian ini bertujuan untuk mengetahui apakah terdapat perbedaan peningkatan literasi siswa antara kelas eksperimen dengan kelas kontrol serta untuk mengetahui seberapa besar perbedaan peningkatan literasinya. Penelitian ini dilakukan di SDN 15 Sungailiat dengan sampel sebanyak 44 siswa kelas 1 . Metode yang digunakan adalah kuantitatif dengan model quasi eksperimen. Teknik pengumpulan data yang digunakan adalah tes. Instrumen yang digunakan adalah tes uraian dengan jumlah 20 butir soal Teknik analisis data yang digunakan adalah uji-t. Hasil dari penelitian yaitu terdapat perbedaan peningkatan literasi kelas eksperimen dengan kelas kontrol, dengan signifikansi data $\mathrm{p}<0,05$; dan uji t dari kelas eksperimen dan kelas kontrol memiliki perbedaan sebesar 3.070. Serta kenaikan literasi antara kelas eksperimen yang menggunakan sastra anak dan kelas kontrol yang menggunakan model konvensional terdapat perbedaan sebesar 17,3\%. Hasil penelitian ini diharapkan dapat membantu siswa dalam meningkatkan literasi anak.
\end{abstract}

\begin{abstract}
This research is motivated by the low interest in reading Indonesian people, especially at the elementary school level. This study aims to determine whether there is a difference in the increase in student literacy between the experimental class and the control class and to find out how big the difference in the increase in literacy is. This research was conducted at SDN 15 Sungailiat with a sample of 44 first grade students. The method used was quantitative with a quasiexperimental model. The data collection technique used is a test. The instrument used is a description test with a total of 20 items. The data analysis technique used is the t-test. The results of the study are that there are differences in the increase in literacy between the experimental class and the control class, with a data significance of $p<0.05$; and the t test of the experimental class and the control class has a difference of 3,070. As well as the increase in literacy between the experimental class using children's literature and the control class using the conventional model, there is a difference of $17.3 \%$. The results of this study are expected to help students in improving children's literacy.
\end{abstract}

\section{PENDAHULUAN}

Sebagai bangsa yang besar, Indonesia harus mampu mengembangkan budaya literasi sebagai prasyarat kecakapan hidup abad ke-21 melalui pendidikan yang terintegrasi, dimulai dari keluarga, sekolah, dan masyarakat. Pintu masuk untuk mengembangkan budaya literasi bangsa adalah melalui perbekalan bahan bacaan dan peningkatan minat baca anak-anak. Sebagai bagian penting dari penumbuhan budi pekerti, minat baca anak-anak perlu dipupuk sejak usia dini dengan lingkungan keluarga. 
Keluarga, sebagaimana menurut Suradika (2019, hlm. 57) merupakan tempat pertama anak belajar dan bersosialisasi.

Dapat dikatakan bahwasanya budaya literasi di Indonesia ini sangat rendah. Terlihat dari penjelasan di atas di mana sejak sekolah menengah pun literasinya tidak diterapkan apalagi untuk sekolah dasar. Terbukti berdasarkan hasil penelitian UNESCO dalam Hastuti dan Lestari (2018, hlm. 30) menjelaskan bahwa selera baca warga Indonesia sejak tahun 2012 hanya 0,001 yang berarti dari seribu orang hanya ada satu orang yang memiliki kategori minat baca dan menduduki posisi 60 bersumber 61 negara. Lebih lanjut menurut Republika dalam Permatasari (2015, hlm. 147) satu fakta lagi yang miris tahap membaca pelajar Indonesia hanya menduduki urutan 57 dari 65 negara. Adapun menurut Nurdiyanti dalam Sudiarta (2017, hlm. 243) mengemukakan bahwa unsur sebab rendahnya kemampuan menulis adalah tradisi kelisanan yang masih mengakar di masyarakat. Untuk itu, menarik dilakukan penelitian dengan judul "Penerapan Sastra Anak dalam Peningkatan Literasi Siswa SD Kelas 1"

\section{KAJIAN LITERATUR}

Menurut Tiarti dalam Suwandi (2019, hlm. 4) literasi dapat dimaknai sebagai kemampuan membaca dan menulis dengan menggunakan sistem bahasa tulis. literasi itu tidak hanya mengenai membaca melainkan juga menulis. Literasi juga dapat kita simpulkan sebagai suatu kegiatan melek aksara dimana kita dapat mengenal huruf yang dapat mengasah kemampuan otak kita dan dapat membuat kita berpikir kritis.
Dengan adanya literasi pun kita dapat menggunakan kemampuan kita untuk menggunakan potensi dan keterampilan dalam mengolah dan memahami informasi saat melakukan aktivitas kegiatan menulis dan membaca.

Menurut Clay dan Ferguson dalam Ulfah, Wahyuni, Hakim (2019, hlm. 126) memaparkan bahwa unsur literasi meliputi:

1) Literasi Dasar

Literasi dasar merupakan kemampuan awal literasi yaitu seperti belajar membaca, menulis, dan melakukan perhitungan angka.

2) Literasi Komputer

Serangkaian keterampilan, sikap, dan pengetahuan yang digunakan untuk mengetahui dan mengoperasikan fungsi awal teknologi informasi dan komunikasi.

3) Literasi Media

Serangkaian keterampilan, kelakuan dan pendirian yang digunakan untuk memahami dan memanfaatkan berbagai struktur media dan format diantara lain keterangan dikomunikasikan dari pengirim ke penerima, sebagai gambar, suara, dan video.

4) Distance Learning dan E-learning

Istilah yang menetapkan dalam keharusan pendidikan dan pelatihan yang memakai jaringan telekomunikasi, lebih spesifik word wide web, dan internet, selaku ruang kelas maya bukan ruang kelas fisik.

5) Literasi Budaya

Literasi budaya yaitu pandangan, dan penafsiran tentang sebuah negara, kelompok etnis, suku, agama, keyakinan dalam menggunakan teknologi.

6) Literasi Informasi

Literasi informasi erat hubungannya pada pembelajaran dalam berpikir kritis yang membentuk tujuan pendidikan formal. 


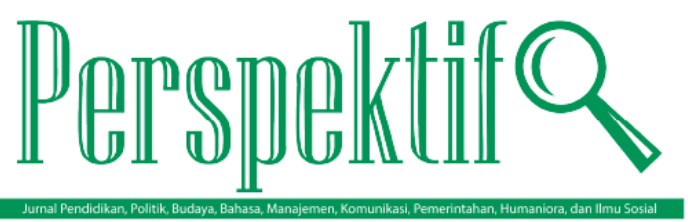

Menurut Wurianto (2017, hlm. 25), literasi adalah refleksi penguasaan dan apresiasi budaya. Berdasarkan capaian makna literasi, literasi sastra secara khusus dapat diartikan ke dalam penguasaan dan apresiasi budaya. Menurut Lukers (dalam Syihabuddin dkk., 2018, hlm. 25) sastra menawarkan dua hal utama yaitu kegemaran dan pemahaman. Dibuktikan hubungan antara sastra dengan literasi berdasarkan peneliti Masnunah (2019, hlm. 19) beliau berpendapat bahwa penggunaan kata menjadikan hal penting dalam berbahasa, lisan maupun tulis. Maka dari itu, penguasaan kosakata seseorang sangat menetapkan keberhasilannya dalam berkomunikasi.

Adapun menurut Kurniawan dalam Faidah (2018, hlm. 126) Bahwa sastra anak mewujudkan sebuah karya sastra yang ceritanya serasi dengan lingkungan anak dan bahasa yang digunakan serasi dengan perkembangan emosional dan intelektual anak. Sastra anak adalah kreasi tulisan yang secara khusus bisa dipahami oleh anak yang berisi tentang kondisi dunia yang akrab dengan anak yang berusia jarak 3-12 tahun (Roysa, 2017, hlm. 19).

Sastra anak merupakan teks atau cerita yang berkisah tentang pengalaman hidup anak. Sastra anak bisa dijelaskan bahwa sebuah karya sastra dimana bahasa dan sisinya serasi dengan usia perkembangan anak serta aktivitas anak, mau itu ditulis oleh pencerita yang telah remaja, dewasa, maupun anak-anak.

Adapun pembagian sastra anak berdasarkan usia menurut Apri, dkk. (2018, hlm. 41):
1) Simbolis awal (3-7 tahun)

Cerita fiksi dibagi menjadi 5, yaitu:

a. Novel dan Cerpen (usia 35 tahun)

b. Fiksi Realistis (usia 10 tahun keatas)

c. Cerita petualangan, cerita keluarga, cerita binatang, cerita sekolah, cerita olahraga.

d. Fiksi Fantasi (usia 5-8 tahun)

e. Cerita Fantasi, Fiksi Fantasi Tinggi, Fiksi Sains,

f. Fiksi Historis (usia 9-12 tahun)

2) Cerita nonfiksi dibagi menjadi 2 yaitu, buku informasi dan biografi.

3) Simbolis Menengah (7-11 tahun)

4) Simbolis Akhir (11-15 tahun)

Sastra anak bukan hanya tentang membaca melainkan menulis dan mencakup bagaimana pengaruhnya terhadap literasi pada anak terkhususnya anak usia 7 tahun atau setara dengan kelas 1 SD (Sekolah Dasar). Berdasarkan uraian diatas yang telah dikemukakan terdapat tujuan dari penelitian ini yaitu untuk melihat pengaruh dari penerapan sastra anak dalam peningkatan literasi siswa SD kelas 1, untuk mengetahui apakah terdapat perbedaan kemampuan literasi siswa SD kelas 1, dan untuk mengetahui seberapa besar keberhasilan dari penerapan sastra anak dalam peningkatan literasi siswa SD kelas 1

\section{METODE PENELITIAN}

Penelitian ini dilakukan di SDN 15 Sungailiat. Berlokasi di Jalan SD 15 No. 13, Parit Padang, Sungailiat, Bangka, Bangka Belitung. Penelitian berlangsung di bulan Februari 2021. 


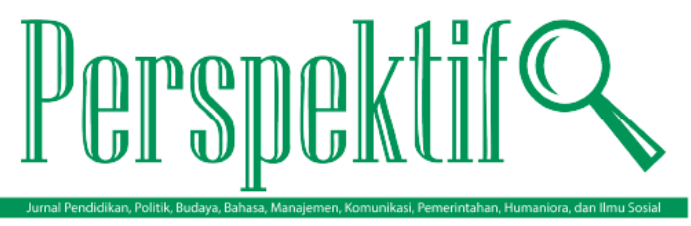

Peneliti menggunakan pendekatan kuantitatif dengan metode eksperimen kuasi. Penelitian eksperimen sangat cocok untuk pengujian hipotesis, untuk mengetahui apakah variabel intervensi atau variabel eksperimen cukup efektif (Suradika, 2000, hlm. 14)

Pendekatan kuantitatif digunakan oleh peneliti untuk memperoleh data atau informasi pelaksanaan penelitian tentang penerapan sastra anak dalam peningkatan literasi pada siswa SD kelas 1. Peneliti akan memberikan soal tes uraian terstruktur yang sudah disiapkan sebelumnya.

Populasi dalam penelitian ini yaitu siswa kelas I di SDN 15 Sungailiat yang berjumlah 50. Pada penelitian ini menggunakan sampel dengan teknik probability sampling melalui model simple random sampling. Dengan demikian jumlah sampel yang digunakan sebanyak 25 orang siswa kelas 1A (kelas kontrol) yang diberi perlakuan dengan model konvensional dan kelas 1B (kategori eksperimen) diterapkan kegiatan dengan metode sastra anak dengan jumlah 25 orang siswa.

Pengumpulan data pada penelitian ini menggunakan tes. Untuk tes soal uraian menggunakan 20 butir soal dengan penilaian menggunakan validitas dan reliabilitas. Setelah data terkumpul maka akan dilakukan uji prasyarat hipotesis penelitian, yaitu menggunakan $N$-Gain score, normalitas, serta homogenitas. Selanjutnya setelah tahapan uji prasyarat selesai maka dilakukan uji penelitian, yaitu dengan menggunakan uji t dengan aplikasi SPSS V.25.

\section{HASIL DAN PEMBAHASAN}

Penelitian ini menggunakan uji $\mathrm{t}$ (uji beda) dengan program software SPSS versi 25. Uji $\mathrm{t}$ bertujuan untuk melihat adakah perbedaan antara sastra anak terhadap peningkatan literasi siswa. Setelah dilakukan pengolahan data, dengan demikian maka diperoleh hasil output dalam bentuk tabel sebagai berikut:

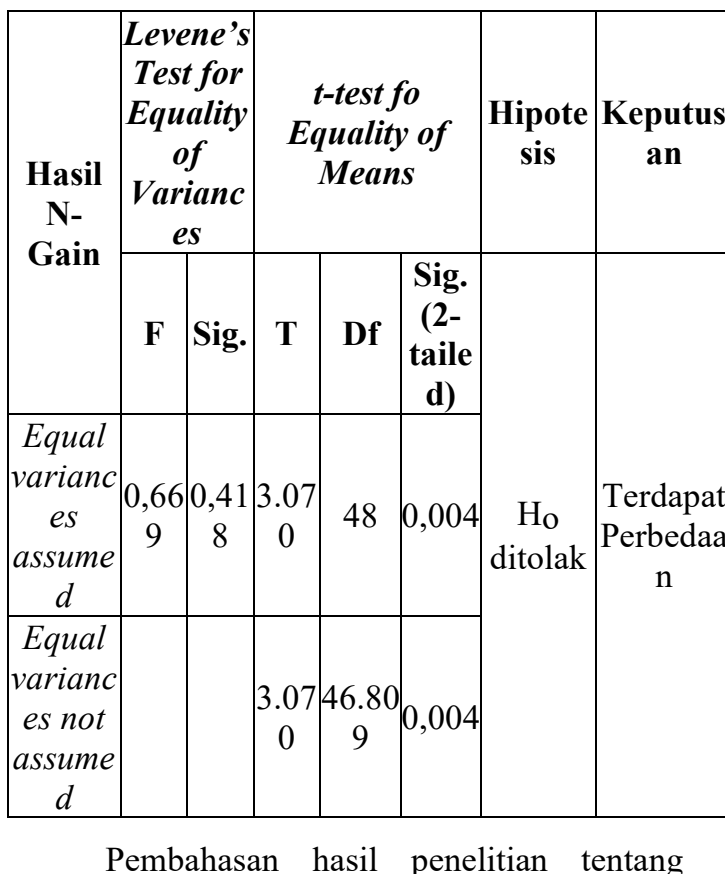

Pembahasan hasil penelitian tentang penerapan sastra anak dalam peningkatan literasi siswa, dengan data yang sudah diolah menggunakan analisis uji t (uji beda). Dalam hasil penelitian dan analisis statistik yang sudah dilakukan di sekolah dasar negeri 15 Sungailiat maka terdapat beberapa interpretasi penelitian, yaitu didapat pembelajaran sastra anak 0,004 kurang berdasarkan tingkat perolehan 0,05 sehingga H1 diterima serta Ho ditolak, sehingga terdapat perbedaan antara siswa yang diberi pembelajaran sastra anak dengan yang tidak diberi sastra anak yang menggunakan model konvensional. Perbedaan skor $\mathrm{N}$-Gain 0,20 pada kelas eksperimen dan kontrol. 


\section{KESIMPULAN}

Hasil penelitian yang dilakukan pada Sekolah Dasar Negeri 15 Sungailiat untuk mengetahui peningkatan literasi yang memakai pembelajaran sastra anak di pembelajaran tematik muatan Bahasa Indonesia kelas 1 disimpulkan sebagai berikut:

Adanya perbedaan literasi antar kelas eksperimen dan kontrol dimana kelas eksperimen pembelajaran lebih baik dari kelas kontrol dengan model konvensional. Dari poin $\mathrm{N}$-Gain uji t bahwa literasi siswa memakai sastra anak lebih tinggi dibanding model konvensional sebesar $0<0,05$.

Pada uji-t kelompok eksperimen dan kontrol adanya disparitas sebanyak 3.070 dimana yang menggunakan pembelajaran sastra anak terdapat kenaikan persentase $17,3 \%$. Dari persentase pre-test $60,5 \%$ posttest $77,8 \%$ didapat rata-rata nilai $N$-Gain kelas eksperimen 0,44 termasuk kategori sedang. Beda menggunakan literasi model konvensional kelas kontrol dengan kenaikan persentase total $9,7 \%$ dimana dalam nilai pretest $60,8 \%$ post-test $70,5 \%$. Rata-rata $N$-Gain dalam kelas kontrol $0,24 \%$ pada kategori rendah. Dari kenaikan persentase total berdasarkan nilai pre-test dan post-test kelas eksperimen $17,3 \%$ dibanding kelas kontrol $9,7 \%$ masih ada perbedaan yaitu sebanyak $7,6 \%$.

\section{REFERENSI}

Faidah, C. N. (2018). DEKONSTRUKSI SASTRA ANAK: MENGUBAH PARADIGMA KEKERASAN DAN SEKSUALITAS PADA KARYA SASTRA ANAK INDONESIA. KREDO : Jurnal Ilmiah Bahasa dan
Sastra, 2(1), 126-139. https://doi.org/10.24176/kredo.v2i1.2 458

Hastuti, S., \& Lestari, N. A. (2018). GERAKAN LITERASI SEKOLAH: IMPLEMENTASI TAHAP PEMBIASAAN DAN PENGEMBANGAN LITERASI DI SD SUKOREJO KEDIRI. Jurnal Basataka (JBT), 1(2), 29-34. https://doi.org/10.36277/basataka.v1i 2.34

Krissandi, A. D. S., Febriyanto, B., Cahya. S, K. A., \& Radityo, D. (2018). Sastra Anak: Media Pembelajaran Bahasa Anak. Dalam D. Radityo (Ed.), Bakul Buku Indonesia (1 ed.). Bakul Buku Indonesia.

Masnunah, F. U. (2019). HUBUNGAN PENGUASAAN KOSAKATA DAN MINAT BACA TERHADAP KEMAMPUAN MENULIS NARASI SISWA KELAS V SD GUGUS CUT MEUTIA, KECAMATAN TAMAN, KABUPATEN PEMALANG. FIP PGSD UNNES

Permatasari, A. (2015, Desember 15). MEMBANGUN KUALITAS BANGSA DENGAN BUDAYA LITERASI. Seminar Nasional Bulan Bahasa.

Roysa, M. (2017). ANALISIS BUKU BACAAN ANAK "BELAJAR SAMBIL BERTERNAK AYAM" BERDASARKAN PENDEKATAN STUKTURAL. KREDO: Jurnal Ilmiah Bahasa dan Sastra, 1(1), 1830.

https://doi.org/10.24176/kredo.v1i1.1 750

Sarwiji Suwandi. (2019). Pendidikan Literasi Membangun Budaya Belajar, Profesionalisme Pendidik, dan Budaya Kewirausahaan untuk Mewujudkan Marwah Bangsa. Remaja Rosdakarya.

Sudiarta, I. W. (2017). Pengaruh Metode Jolly Phonics Terhadap Kemampuan Membaca Dan Menulis Permulaan Bahasa Inggris Pada Anak Kelompok B TK Mahardika Denpasar. Jurnal Ilmiah Pendidikan dan Pembelajaran 
PPs Universitas Pendidikan Ganesha, 14(1), 164-175. https://doi.org/10.23887/JIPP.V1I3.1 1989

Suradika, A. (2000). Metode Penelitian Sosial. UMJ Press.

Suradika, A. (2019). Pendidikan Keluarga dan Keluarga Berpendidikan Perspektif Islam. Direktorat Advokasi dan KIE BKKBN.

Syihabuddin, S., Damaianti, V. S., Apriliyani, N. Y. A., \& Istianingrum, R. (2018). Perencanaan Pengembangan Instrumen Penilaian Sikap pada Apresiasi Sastra Anak. Lingua Franca:Jurnal Bahasa, Sastra, dan Pengajarannya, 2(2), 22. https://doi.org/10.30651/lf.v2i2.2205
Ulfah, S. M., Wahyuni, S. A., \& Hakim, L. (2019). IMPLEMENTASI

STRATEGI

DALAM PENGEMBANGAN BUDAYA LITERASI DI PROGRAM STUDI PENDIDIKAN ISLAM ANAK USIA DINI. Seminar Literasiologi, 119.

Wurianto, A. B. (2017). Literasi Sastra dalam Masyarakat Belajar (Learning Society). Prosiding SENASBASA (Seminar Nasional Bahasa dan Sastra), 1(1), 24-29. https://doi.org/10.22219/.V1I1.1742 